\title{
Coping with Economic and Monetary Instability \\ - Conditions of Monetary Stability - Can they be Reached?*
}

\author{
by Helmut Schlesinger**
}

\section{Introduction}

Monetary stability has numerous aspects; the domestic monetary stability which means the absence of inflation. The external stability of the currency, which means nowadays the stability of the real exchange rate (i.e. no loss of the purchasing power of a currency in relation to other currencies) and last but not least: the stability of the financial system; the absence of a possibility of the systemic failure of the financial sector.

A traditional view, especially from the side of Central Banks would be: if the domestic monetary stability is given over a longer period then the external stability and the stability or the financial system are secured. I think over the longer run this is indeed granted. But if we look at the present situation in the world, we find a rather paradoxical situation.

The industrial countries are in an upward movement, measured by their real GDP, some for the last four years (USA, UK), some since two years (Germany and other European countries) and Japan since one and a half year. On the other hand inflation is rather moderate; in the G-10-countries no higher than $3 \%$ p.a. except the UK (31/2\%) and Italy $(5 \%)$. This is not an ideal stability but remarkably better than during the eighties, not to speak of the seventies. Many countries have decided to follow an anti-inflationary policy, accepting higher unemployment for a while and moderate wage increases. Only the USA and Japan have a high disequilibrium in their balance of payments; the US-deficit is of 150-160 bn \$, the Japanese surplus 120-130 bn \$. Even these differences are not new, they have existed for a number of years, but they are now big and no decline can be discovered.

Except for the disequilibrium between US and Japan, the so called "fundamentals" in the other industrial countries - growth, price stability, balance of payments - are certainly not in an ideal but in a rather good position.

On the other hand the fluctuations in the exchange markets are - and have been rather strong even among some countries of the EU. During the last 15 months the DMark 1995.

* Paper presented of the 22nd General Assembly of the Geneva Association, London, May 25,

${ }^{* *}$ Former President of the Central Bank of Germany (Deutsche Bundesbank). 
revalued about $20 \%$ vis-à-vis the US-Dollar and the revaluation of the Yen was even stronger. One should not forget that before this period the dollar has revalued by quite a considerable amount; at the beginning of September 1992 the dollar exchange rate vis-à-vis the DMark was very low. On the one hand we can observe a wide band of fluctuations more than $10 \%$ in each direction around the trend. On the other hand, there exists a continuous long term downward trend of the US-Dollar vis-à-vis the D-Mark and - even more pronounced vis-à-vis the Yen.

\section{The fluctuations in the foreign exchange markets}

Let me go a little further into an analysis of these movements because - unfortunately - they are not only an expression of uncertainties in the world economy, they are also creating these uncertainties by themselves on the side of the market participants as well as on the side of the policy makers.

For me it seems not so difficult to explain the long term trend of the US-Dollar. Since the sixties the dollar had to be considered as a candidate for devaluation - from 4.20 DM to 1.45 DM or from 360 Yen to 87 Yen. And the same degree of devaluation is more or less true vis-à-vis the Swiss franc, the Dutch guilder, the Austrian shilling and other hard currencies. Taking into account the so called purchasing power parity (PPP, which is not really decisive) one could describe this period as the route from an overvalued dollar during the Bretton Woods-System of fixed exchange rates to an undervalued currency now. In other words: from an undervalued DM, Yen and other hard currencies to an overvalued currency now.

But this explanation is not really convincing. The theory of floating exchange rates would deliver another answer: that over the longer run the exchange rates are bringing the countries into a new equilibrium partly through a change in the trade flows and partly through capital movements. In this context the USA-Japan case is of particular importance Because during that long period of a revaluation of the Yen trade and capital flows are not following this model, the trade surpluses are even growing and the capital exports from Japan to the USA have been diminished. Whatever the reasons for this inflexible response to the big change of the exchange rates of these two economies are (it could be the compensation of the revaluation of the Yen with lower costs of production), and the unpreparedness of the US-industry to fight for higher market shares in Japan - Vice Minister Sakomoto said this week: the three big US-car-producers offer only two cars with right-hand-drive -, these discrepancies have a destabilizing effect for the whole world economy.

Besides this inflexible response of the trade flows - a problem which, in my opinion, cannot be solved by any type of a trade war - the capital movements over the border in the case of USA and Japan create additional problems instead of solving them. In 1994 the USA did not have any long-term net capital imports; the deficit of the current account had to be financed on a short term basis, partly with the help of foreign central banks increasing their US-Dollar-holdings. I think we can find here a particular explanation for the disequilibrium. Even if the US longterm interest rates were not low, they were not high enough to attract foreign investors, especially not high enough to compensate the risk of a further devaluation of the dollar. This risk is not so much found at the present domestic conditions in the USA. Price increases are not high, wage increases moderate, the economy is growing since a longer period, this exchange rate risk is the consequence of the long term memory of the market, the long term devaluation of the dollar. 
The particular problem is that in the USA private persons and many politicians don't care very much about the devaluation: For them the dollar is the dollar. The dependence of their currency on international developments is not really evident to the normal citizen. And the official attitude is very often of the type: "The dollar is our currency but your problem" (Connally).

This would be a too simple view of the world; it is certainly not shared by responsible persons in the administration, the Federal Reserve System, and the financial sector in the US. In fact, the devaluation trend of the US-Dollar is rather costly for the US economy and their citizens. Over the long run the devaluation has led to a longterm deterioration of the US terms of trade. In other words: in real terms the USA have to deliver constantly more exports to pay for the same quantity of imports. Per se, this is a loss for the living standard of the nation. The fact that the average real income of the mass of wage and salary earners was not higher in 1994 than in 1960 has - to a certain degree - to be attributed to the long term detoriation of the terms of trade. The other side of the coin is the improvement of the terms of trade for the countries with a continuing revaluation of their currency. I should add that the problems of the European countries among themselves are not of this magnitude. The main devaluing countries in the EU - Italy, Sweden, Finland, Spain, Portugal - can be considered as having more elasticity on the part of their trade flows. They can use the improvement of their competitiveness as a consequence of the devaluation to change the trade balance to their advantage. And they can reach once more a certain attractiveness for capital imports if the markets judge the political situation as rather stable. Here, the judgement in terms of government finances is of particular importance.

Unfortunately in Europe the public finance situation has not shown much improvement during the years of the recent upward movement of their economies. In a majority of EC countries the budget deficits are surpassing the Maastricht Criterion of 3\% GDP. This was not only the case for 1994; first indications for 1995 (as far as available) show no bigger improvement with the exception of Germany. Outside the EU, Switzerland and Japan have had and still have a rather small budget deficit. In other words: Those countries which do not have high amounts of public sector borrowing need are attractive to foreign capital and can have relatively low interest rates because they gain a bonus for being a country with a stable or even revaluing currency. In other words: One of the most important handicaps reaching an equilibrium situation in the foreign exchange markets on the longer term are the unsolved budget problems of a number of countries and, in many cases since a long period.

\section{The fluctuations and the economic "fundamentals"}

As I said the longer term movements of exchange rates among the greater number of industrial countries can be explained even under the present conditions as the consequence of given disequilibria. But it is much more difficult to qualify the economic reasons for the high degree of the short term volatility of floating exchange rates. In a large study of a "Bretton Woods Committee" - a private group - a graph tells us that in the period after the Bretton Woods-System (1971/73) the fluctuations of the US-DM rate around the trend from one month to another has been very often up to $5 \%$ plus and minus and in a number of cases up to $10 \%$ plus and minus around the trend. 
What are the main reasons behind these large short term fluctuations which cannot be explained by a change in the "fundamentals"? On the one side the strongly growing flow of international financial transactions, with enormous magnitudes in rather short periods, are creating short term deficit and surplus positions in different currencies and the arbitrage needs attractive differences of the change of the exchange rates to work in the expected direction. But the main reasons for this fluctuation are - generally speaking - the changes in short term expectations which are the result of a network of informations, calculations and speculations about the future consequences of actual economic and political events, together with the anticipated reaction of central banks included. Daily, hundreds and thousands of traders make their bets about the short term changes of exchange rates. Certainly the global economic consequences of wide short term fluctuations are not positive. The basis for economic decisions is unstable; uncertainties have to be taken into account and insurance against this risk can be sought in the future markets by hedging, but it is costly. The question remains: Can one avoid those fluctuations?

\section{In search of a solution}

There are two different necessary answers. As far as the long term trend of exchange rates is concerned, the solution lays in the improvement of the fundamentals. Looking back to the second half of the eighties and the first half of the nineties there is hope that many countries have convincingly changed their attitude against inflation. Central banks of some countries have declared price stability targets between $1-3 \%$, and they are on the way to attaining it. Other central banks orientate their policy on monetary targets (as do the Bundesbank and the Swiss National Bank) - and smaller countries try to keep the exchange rate vis-à-vis another stable currency. This "targeting" is the expression that policy criterias should be guided by a more or less objective target, moving away from judging monetary policy at only the interest rate level and the interest rate structure. I think that in most industrial states monetary policy has improved the conditions for a nearly stable price level, also an important precondition for more stable exchange rates.

I would be happy if I could judge the government financial policy equally positively. It is true that many countries formulate relatively strong plans to reduce the government deficit and that tax increases are not mentioned in the first line of those plans. In many countries the overall tax burden has reached a high level which is negative for growth and, at the end, negative also for tax revenues and the budget. Germany belongs to these countries. The remarkable decline of the deficit in 1995 is to a great extent the consequence of a further tax increase.

A real improvement of the budget situation can only be reached on the expenditure side. Being realistic: I do not believe in the possibility of cutting the actual amount of expenditure. But it is very helpful if a country can keep the increase of government expenditure significantly under the growth rate of nominal GDP and tax revenues. West Germany strongly practiced such a rule in the years 1983 to 1989 with positive results at the end for the deficit and for the possibility to lower direct taxes without increasing the deficit.

The question is: How can countries work together to reach better results in this field? For the EU-countries a surveillance process is obligatory. The member countries - through the Council of Ministers of Finance - can give recommendations to a single country to 
strengthen the budget policy and this can support the position of the government vis-à-vis its parliament if it follows these recommendations. Nevertheless in the final outcome the countries are autonomous as far as the fiscal policy is concerned.

The G-7 meetings for coordinating macro-economic policies among these big industrial countries also discuss these matters. But the results are not overwhelmingly impressive. Not infrequently the elephant in this famous common boat tries to convince the smaller animals what they should do to ease the problems of the elephant. If one is an elephant this seems to be very rational but for the world in total it would only be helpful if the mighty partner himself is on the right track and is leading the others in the right direction.

Last year, the Bretton Woods-Conference which was influenced by leading persons like Paul Volker, Wilfried Guth, R. Debs and Y. Kashiwagi - came to the conclusion that countries should strengthen their fiscal and monetary policies and "should establish a more formal system of coordination, involving firm and credible commitments, ... and avoid excessive exchange rate misalignments and volatility". And it adds: "the IMF should be given a central role in coordinating macro-economic policies".

One could subscribe to the general line of this advice, given the aforementioned conditions of firm and credible commitments. Here is the weak point of all those attempts at international agreements, because they have to strike a balance between the national interests of each country and the global situation. They usually tend to be vague and not binding.

My own experience in this field leads me to the conclusion that the most important agreement between the countries would be for each to promise to bring its own house in order. In other words: not to expect - except under extraordinary circumstances - that instead the community of countries would do it. This is especially important in the field of exchange rate policies. Whatever the difficulties of the fluctuations of the exchange rates are, it is better to live with them rather than with a world-wide regime of fixed exchange rates or target zones without economic convergence. The reason for this is that under fixed exchange rates between countries of different macro-economic conditions and different political targets - worldwide these differences can not be abolished - the tendency exists to keep the exchange rates unchanged for too long to avoid realignments as long as it is possible. The usual consequence is in the end a large correction when a severe crisis on the foreign exchange markets has made it unavoidable.

\section{The role of the European Monetary Union}

Having said this for the worldwide markets, I do not think that one must be as sceptical for the European Union. On the one side, the convergence-process is making remarkable progress between a majority of countries of the EU. And secondly one important change has been made in order to avoid the last crisis of the ERM in July/August 1993; I mean the enlargement of the fluctuation band for ERM-currencies from $2 \frac{1}{4} \%$ resp. $6 \%$ to $15 \%$. Since that time at least 3 factors have changed:

1. The speculation against a devaluation of a currency in the ERM has diminished; there is no more a oneway risk of a speculation possible as there was in the period of very small margins.

2. It is more clear than before that the responsibility for the currency of a country and its exchange rate lays primarily on the side of this country and not on the side of the others. 
3. Because the convergence among most countries in the ERM has rcached a relatively high degree, the tensions have been diminished, even though they have not completely disappeared.

It had been said that under the conditions of a wide band for the fluctuation of exchange rates, the possibilities for a European currency union have been diminished. I do not agree with this argument. One should not forget that during the last $1 \frac{1}{2}$ years big devaluations among EU-currencies have concerned those currencies which are not in the ERM - the Lira, the Swedish Kronor, the British Pound -. The devaluations among ERM-currencies, especially the Peseta, have led to a more realistic exchange rate. Certainly these movements are not in line with the particular entrance criterias into the EMU. These criteria do not allow a devaluation during the last two years before the entrance in this planned union; it would exclude those currencies from a start in 1997, but not necessarily for 1999, a much more realistic date.

Nevertheless my feeling is that the enthusiasm for the EMU has not increased during the recent past and maybe the contrary can be observed. I do not see that in the meantime the economic arguments for or against an EMU have changed. There are not many voices arguing against the clear pro-arguments of a single currency in a single market: In a monetary union there is no foreign exchange rate risk, there are less transaction costs and it conforms with the idea of having one market without any barriers. The economic contraarguments are those of the missing convergence and the doubts that a currency as stable as the DM, the Guilder or the Schilling can ever be matched, because of the different stability culture among the member countries. I am not so pessimistic, at least not for the core-countries in the middle of Western Europe. There is a widespread wish to avoid inflation and to give full independence to the National Central Banks now and the ECB later.

Some sceptical arguments which have been brought forward recently are more of technical nature. The necessary time and the costs for a conversion from national currencies to one single currency are strongly mentioned. After my own practical experience these arguments - which are generally justified - may be a little overstated. It seems to me that the governments are not accelerating this process, contrary to the European Parliament which is pleading for a shorter period between the definite fixing of exchange rates and the substitution of the national currencies by the single european currency. For instance - since a long time - the German government says that the name of a common singlc currency is not yet defined, the word ECU describes only the abstract existence of a European Currency Unit. If this has been the basis of the signature of the Treaty - if it is not decided, that the name is ecu, presumably it is so-, then I think it is high time that a commonly agreed name is found.

The governments have signed the Treaty more than 3 years ago, a long time to resolve this question. I ask myself if one has to assume behind this reluctant attitude a certain retreat of the governments from their previous courage. But if one keeps the target of the European Monetary Union as a realizable target - on the basis of the Treaty of Maastricht it is realizable - then the contrary would be necessary: The public has to be better informed, has to be confronted with the pluses and minuses of this very important target, which - as is anything else on the way to a European Union since 1952 - primarily is a political target but with high economic consequences. 
If we consider the question of monetary stability under the particular conditions of the European Union I think it is worth not to give up the plan of a European Monetary Union with all the necessary preconditions and options which are written in the Treaty of Maastricht. Economically it would help to strengthen the monetary stability in Europe and presumably also in the world. 